\title{
Fluxes of carbon and nutrients to the Iceland Sea surface layer and inferred primary productivity and stoichiometry
}

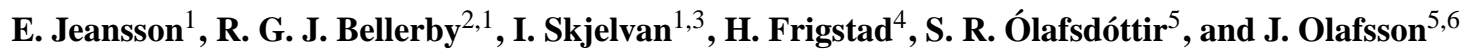 \\ ${ }^{1}$ Uni Research Climate, Bergen, Norway \\ ${ }^{2}$ Norwegian Institute for Water Research (NIVA), Bergen, Norway \\ ${ }^{3}$ Geophysical Institute, University of Bergen, Bergen, Norway \\ ${ }^{4}$ Norwegian Environment Agency, Oslo, Norway \\ ${ }^{5}$ Marine Research Institute, Reykjavik, Iceland \\ ${ }^{6}$ Institute of Earth Sciences, University of Iceland, Reykjavik, Iceland \\ Correspondence to: E. Jeansson (emil.jeansson@uni.no)
}

Received: 29 September 2014 - Published in Biogeosciences Discuss.: 6 November 2014

Revised: 5 January 2015 - Accepted: 19 January 2015 - Published: 12 February 2015

\begin{abstract}
This study evaluates long-term mean fluxes of carbon and nutrients to the upper $100 \mathrm{~m}$ of the Iceland Sea. The study utilises hydro-chemical data from the Iceland Sea time series station $\left(68.00^{\circ} \mathrm{N}, 12.67^{\circ} \mathrm{W}\right)$, for the years between 1993 and 2006. By comparing data of dissolved inorganic carbon (DIC) and nutrients in the surface layer (upper $100 \mathrm{~m})$, and a sub-surface layer $(100-200 \mathrm{~m})$, we calculate monthly deficits in the surface, and use these to deduce the long-term mean surface layer fluxes that affect the deficits: vertical mixing, horizontal advection, air-sea exchange, and biological activity. The deficits show a clear seasonality with a minimum in winter, when the mixed layer is at the deepest, and a maximum in early autumn, when biological uptake has removed much of the nutrients. The annual vertical fluxes of DIC and nitrate amounts to $2.9 \pm 0.5$ and $0.45 \pm 0.09 \mathrm{~mol} \mathrm{~m}^{-2} \mathrm{yr}^{-1}$, respectively, and the annual airsea uptake of atmospheric $\mathrm{CO}_{2}$ is $4.4 \pm 1.1 \mathrm{~mol} \mathrm{C} \mathrm{m}^{-2} \mathrm{yr}^{-1}$. The biologically driven changes in DIC during the year relates to net community production (NCP), and the net annual NCP corresponds to export production, and is here calculated as $7.3 \pm 1.0 \mathrm{~mol} \mathrm{C} \mathrm{m}^{-2} \mathrm{yr}^{-1}$. The typical, median $\mathrm{C}: \mathrm{N}$ ratio during the period of net community uptake is 9.0 , and clearly higher than the Redfield ratio, but is varying during the season.
\end{abstract}

\section{Introduction}

Increasing our knowledge of the oceanic cycles of carbon and nutrients, and how they are linked, is crucial for improving ocean biogeochemical models and, thus, producing better projections of oceanic response and feedback to a changing climate.

The biological carbon pump (i.e. the biologically driven transport of carbon from the surface waters to the deep ocean) is a pathway that can sequester atmospheric $\mathrm{CO}_{2}$ on long timescales (Falkowski et al., 1998; Sabine et al., 2004). With the present increase in atmospheric $\mathrm{CO}_{2}$ (http://www. esrl.noaa.gov/gmd/ccgg/trends/global.html) the strength of the future biological carbon pump is very uncertain, and warrants further investigation (e.g. Passow and Carlson, 2012). To be able to reveal changes in the oceans, we need repeated measurements and long-term time series stations, such as the Hawaii Ocean Time series (HOT) and the Bermuda Atlantic Time series Study (BATS) (e.g. Church et al., 2013). In the Nordic Seas, the time series stations in the Norwegian Sea (ocean weather station Mike) and the Iceland Sea, have greatly increased our knowledge of the carbon cycle in this region (e.g. Skjelvan et al., 2008; Ólafsson et al., 2009). In this paper, we focus on the Iceland Sea, which is the shallowest of the main basins in the Nordic Seas. The Iceland Sea (Fig. 1) is most often defined as the waters delimited by Greenland in the west; the Denmark Strait and the continental shelf break south of Iceland to the south; by Jan Mayen 


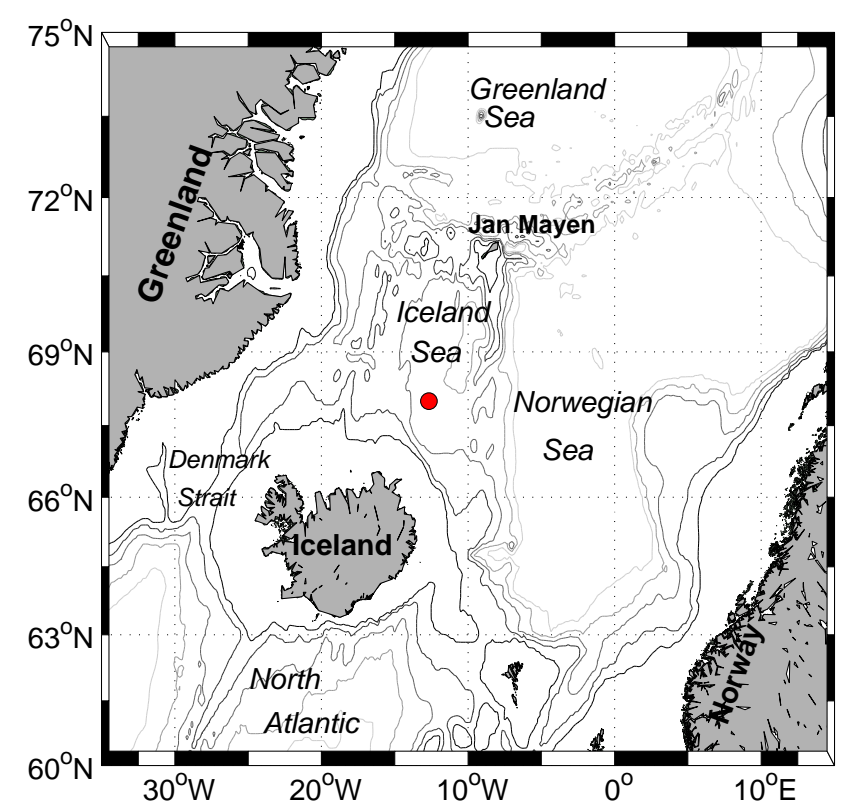

Figure 1. Map of the Nordic Seas region. The red filled circle marks the position of the time series station.

and the Jan Mayen Fracture Zone to the north and by the Jan Mayen Ridge to the east (Pálsson et al., 2012). The hydrographic properties of the Iceland Sea can generally be described as Arctic Intermediate Water overlying Arctic Deep Water (e.g. Swift and Aagaard, 1981). See Assthorsson et al. (2007) for a more detailed description.

The biological carbon pump in the Nordic Seas has not been studied in great detail, and we need to improve our understanding of the driving processes. Until now there are few estimates of the primary productivity in the relatively cold and low-salinity Arctic waters that dominate the upper water column of the Iceland Sea. Production estimates in this Arctic domain are in the range $75-179 \mathrm{~g} \mathrm{C} \mathrm{m}^{-2} \mathrm{yr}^{-1}$, based on data and remote sensing (Thordardottir, 1984; Zhai et al., 2012).

There are several production terms used in the literature, illustrating somewhat different fluxes. New production, as defined by Dugdale and Goering (1967), is the production that results from allochthonous (new) nitrate added to the surface layer by vertical or horizontal advection, or via airsea exchange. This is different from total production, which also includes nitrogen regenerated within the surface layer (see Dugdale and Goering, 1967). Net community production (NCP) is defined as net primary production minus community respiration (e.g. Platt et al., 1989). Estimates of NCP have traditionally been based on bottle oxygen incubations (Gaarder and Gran, 1927), but are often based on oxygen budgets (e.g. Falck and Gade, 1999) or seasonal mixed-layer changes in oxygen or inorganic carbon, corrected for the air-sea fluxes (e.g. Körtzinger et al., 2008; Frigstad et al., in preparation), or oxygen-to-argon $\left(\mathrm{O}_{2} \mathrm{Ar}^{-1}\right)$ ratios (e.g.
Reuer et al., 2007; Quay et al., 2012). Export production is the excess organic matter produced in the euphotic zone, on top of the production needed to sustain the productive system (Dugdale and Goering, 1967; Eppley and Peterson, 1979). Thus, the export production cannot exceed the rate of added nutrients (i.e. new production), and these fluxes have been assumed to be equivalent on an annual average (Eppley and Peterson, 1979).

An issue under debate over the last few decades, is the universal validity of the so-called Redfield ratio, describing the stoichiometry between carbon and inorganic nutrients in marine plankton, where the average $\mathrm{C}: \mathrm{N}: \mathrm{P}$ ratios are 106:16:1 (Redfield et al., 1963). Observations of deviations from this relationship are numerous (e.g. Takahashi et al., 1993; Anderson and Sarmiento, 1994; Daly et al., 1999; Körtzinger et al., 2001; Koeve, 2006, Tamelander et al., 2013; Frigstad et al., 2014). It is common practise to use the traditional Redfield ratio to convert changes of nutrients into production of organic matter, both in observational and model studies (e.g. Skjelvan et al., 2001; Falck and Anderson, 2005; Skogen et al., 2007), so any significant variability or deviations of these ratios could have a marked impact on estimated primary production.

In this study we use observational data of inorganic nutrients (nitrate, phosphate, and silicate) and inorganic carbon (total dissolved inorganic carbon (DIC) and $p \mathrm{CO}_{2}$ ) from the upper layers of the Iceland Sea to evaluate annual fluxes of carbon and nutrients into the surface layer, which we here define as the upper $100 \mathrm{~m}$ of the water column. From these fluxes we estimate the long-term mean in primary production in the Iceland Sea, and the related stoichiometric relationships.

\section{Data}

The study utilises data from the Iceland Sea time series station, located at $68.00^{\circ} \mathrm{N}, 12.67^{\circ} \mathrm{W}$ (Fig. 1). Surface sampling of DIC and $p \mathrm{CO}_{2}$ started in 1983, and water column sampling for DIC and $p \mathrm{CO}_{2}$ started in 1991 and 1993, respectively (Ólafsson et al., 2010). Here we include data of inorganic carbon, nutrient and hydrography between 1993 and 2006. For details of analytical methods and data quality, see Olsen (2009), Olafsson and Olsen (2010) and Olafsson et al. (2010). The data are available via the CARINA database (http://cdiac.ornl.gov/oceans/CARINA/).

Monthly long-term surface wind speed data are from the NCEP/NCAR reanalysis project (Kalnay et al., 1996), provided by the NOAA/OAR/ESRL PSD, Boulder, Colorado, USA, from their web site at http://www.esrl.noaa.gov/psd/.

For the atmospheric $\mathrm{CO}_{2}$ near Iceland we use Globalview data from Vestmannaeyjar, south of Iceland, ICE_01DO (GLOBALVIEW-CO2, 2012), and the barometric pressure are monthly means of sea level pressure (SLP) obtained from NOWW Fisheries Service, Environmental Research Division (http://www.pfeg.noaa.gov/products/las.html). 
Table 1. Monthly computed median mixed layer depths (MLDs) and entrainment velocities $\left(v_{\text {mix }}\right)$. These are used when calculating the vertical fluxes. The values in italic are interpolated from surrounding monthly data. See text for details.

\begin{tabular}{lrrr}
\hline Month & $\begin{array}{r}\text { MLD } \\
\text { median (m) }\end{array}$ & $\begin{array}{r}v_{\text {mix }}{ }^{\text {a }} \\
\left(\mathrm{m} \mathrm{month}^{-1}\right)\end{array}$ & $\begin{array}{r}\text { Number of } \\
\text { sampled months }\end{array}$ \\
\hline 1 & 118 & -29 & 2 \\
2 & 147 & -29 & 16 \\
3 & 168 & -21 & 3 \\
4 & 116 & -3 & 1 \\
5 & 65 & -3 & 14 \\
6 & 30 & -3 & 8 \\
7 & 25 & -3 & 1 \\
8 & 21 & -3 & 16 \\
9 & 32 & -11 & 4 \\
10 & 37 & -5 & 4 \\
11 & 59 & -22 & 14 \\
12 & 89 & -30 & 2 \\
\hline
\end{tabular}

a $v_{\text {mix }}$ is defined as negative to get a negative flux into the surface layer.

$\mathrm{b}$ This is the number of sampled months in the data set. For months sampled less than three times, interpolated numbers have been used.

\section{Methods}

This study is based on the climatology (long-term means) of the hydrographical and chemical properties observed in the Iceland Sea. We calculated long-term monthly mean profiles by averaging all data for every month, for the chosen depths (every $10 \mathrm{~m}$ in the upper $300 \mathrm{~m}$, every $50 \mathrm{~m}$ between 300 and $500 \mathrm{~m}$, and then every $100 \mathrm{~m}$ from 500 down to the bottom $(1900 \mathrm{~m}))$ and further interpolated to the chosen depth intervals, using piecewise cubic Hermite interpolation in Matlab ${ }^{\circledR}$ (e.g. Fritsch and Carlson, 1980).

The sampling frequency for the different months during the course of the time series sampling is shown in Table 1 . The sampling program of the time series station is largely quarterly (February, May, August, and November), which is clearly seen in Table 1. Four months (January, April, July, and December) have been sampled less than three times, and for these months we use interpolated values.

The wintertime mixed layer in the Iceland Sea typically reaches down to $200 \mathrm{~m}$ at the end of the winter mixing (Ólafsson, 2003), which is supported by our calculated mean mixed layer depth (MLD) (Fig. 2). We tested several criteria for the MLD, based on either a difference in temperature $\left(\Delta T=0.2^{\circ} \mathrm{C}\right)$, or density $\left(\Delta \sigma_{\theta}=0.01,0.03,0.05\right.$, and $0.125 \mathrm{~kg} \mathrm{~m}^{-3}$ ), all referenced to a near-surface value at $10 \mathrm{~m}$ (e.g. de Boyer Montégut et al., 2004). The temperature criteria gave unreasonably deep winter convection, with median values of $600-800 \mathrm{~m}$. All density criteria were shallower, however, the $0.125 \mathrm{~kg} \mathrm{~m}^{-3}$ criterion gave a median winter MLD of nearly $400 \mathrm{~m}$, which is not supported by depth profiles of hydrography or biogeochemical parameters (Fig. 3), or by previous estimates (e.g. Ólafsson, 2003). The den-

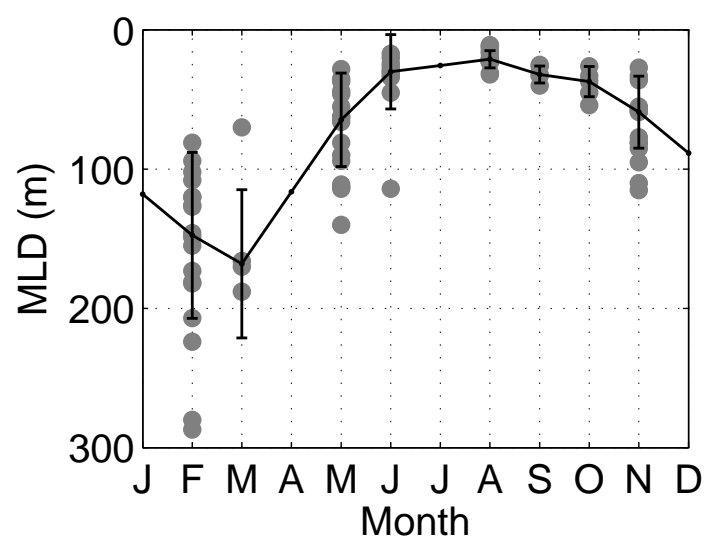

Figure 2. Calculated mixed layer depth (MLD) at the Iceland Sea time series station, using the density difference criteria of $\Delta \sigma_{\theta}$ $0.05 \mathrm{~kg} \mathrm{~m}^{-3}$. The grey dots show the MLD for each year, and the line is the median of the values for each month, and the error bars show the standard deviation (SD). The values for the months without shown data are interpolated.

sity difference criteria $\Delta \sigma_{\theta}=0.05 \mathrm{~kg} \mathrm{~m}^{-3}$ showed the highest agreement with Ólafsson (2003) and was also used by Zhai et al. (2012), which is why we adopted this criteria in the present study. However, the seasonal drawdown in nutrients and DIC (see Fig. 3) is largely confined to the upper $100 \mathrm{~m}$. Based on this we define the upper $100 \mathrm{~m}$ as the surface layer, and calculate the climatological fluxes in and out of this layer. The approach is described in detail below.

\subsection{Calculation of deficits}

We apply a box-model approach, which was developed for idealised annual plankton cycles (Evans and Parslow, 1985), and has been applied in, for example, the Greenland and the Norwegian seas (Anderson et al., 2000; Skjelvan et al., 2001; Falck and Anderson, 2005). Here we compute deficits (DEF) of nutrients and DIC in the surface layer relative to a defined sub-surface layer:

$\operatorname{DEF}_{X}=\int_{100}^{0}\left(\left[X_{\mathrm{SSL}}\right]-\left[X_{\mathrm{SL}}\right]\right)$,

where $X$ is the concentration of the constituent of interest (here nutrients and DIC), SSL is the sub-surface layer, and $\mathrm{SL}$ is the surface layer. Thus the deficit increases when there is a decrease in carbon or nutrients in the surface layer. While the surface layer is chosen to be the upper $100 \mathrm{~m}$, the subsurface layer is defined as the layer between 100 and $200 \mathrm{~m}$, for which monthly mean concentrations are calculated and applied in Eq. (1). Applying this on the monthly mean profiles, the deficits are calculated for every $10 \mathrm{~m}$ interval in the upper $100 \mathrm{~m}$, relative to the monthly mean concentration in the sub-surface layer, multiplied with 10, and summed up for each month (Anderson et al., 2000). 

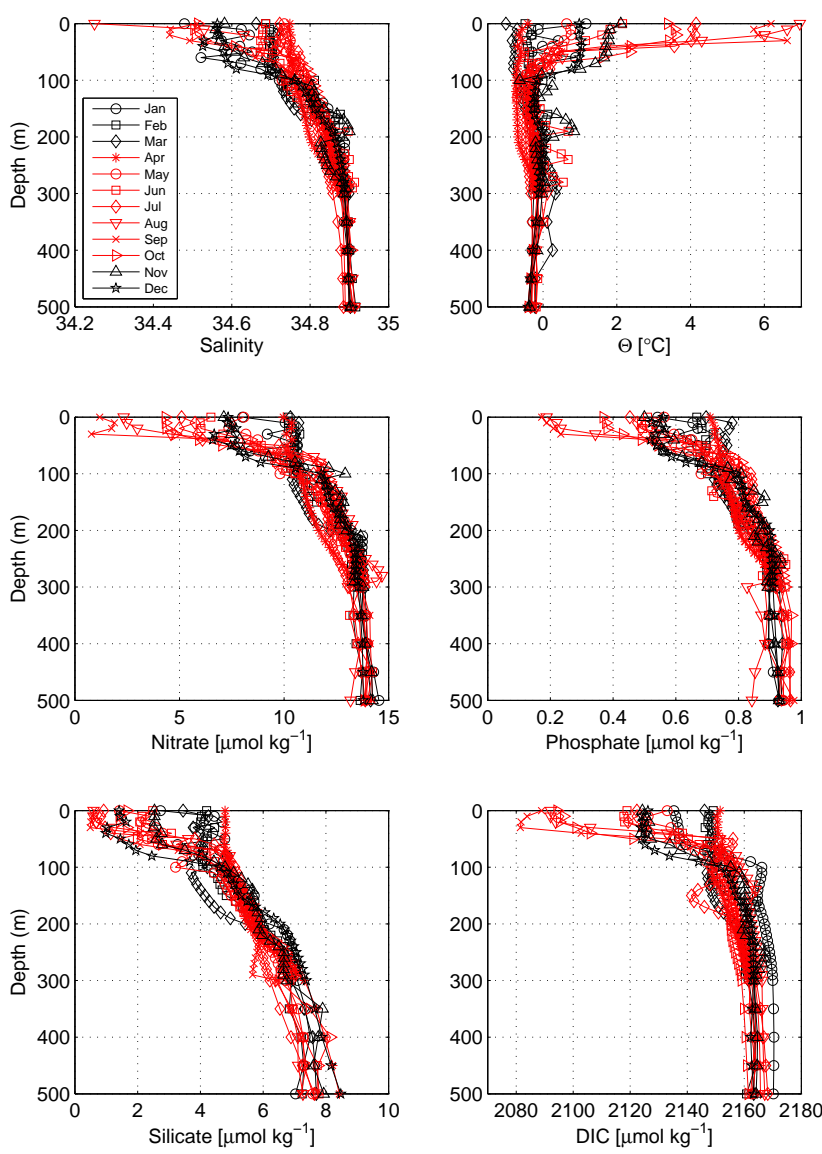

Figure 3. Mean monthly concentration profiles (upper $500 \mathrm{~m}$ ) in the Iceland Sea, of salinity (upper left), potential temperature (upper right), nitrate (middle left), phosphate (middle right), silicate (lower left), and DIC (lower right). The black profiles indicate months with an increase in MLD (compared to previous month) and the red profiles depict months with a decreased or very shallow $(<40 \mathrm{~m})$ MLD (see Fig. 2).

\subsection{Flux calculations}

The change in the deficit $\left(\Delta \mathrm{DEF}^{X}\right)$ of constituent $X$ are explained by the sum of the fluxes into and out of the surface layer; the vertical exchange with the deeper layers $\left(F_{\text {vert }}\right)$, the horizontal fluxes $\left(F_{\text {hor }}\right)$, the biological production $\left(F_{\text {bio }}\right)$, and the air-sea exchange $\left(F_{\text {atm }}\right)$ :

$$
\Delta \mathrm{DEF}^{X}=F_{\text {vert }}^{X}+F_{\text {hor }}^{X}+F_{\text {bio }}^{X}+F_{\text {atm }}^{X} .
$$

Positive fluxes indicate a transport out of the surface layer. Regarding the time series station as a very thin section the horizontal fluxes will balance, and $F_{\text {hor }}$ could then be set to zero. We also assume no atmospheric input of nutrients, and thus $F_{\text {atm }}$ is only of importance for the calculations of the DIC fluxes. The uncertainty in the different fluxes is estimated from error propagation of the standard deviations of the different terms in the flux calculations. The uncertainties are discussed in Sect. 6.
The vertical flux to the surface layer can be calculated from Eq. (3) (Anderson et al., 2000; Skjelvan et al., 2001; Falck and Anderson, 2005):

$F_{\text {vert }}^{X}=\frac{v_{\text {mix }}}{H} \mathrm{DEF}^{X}$,

where $v_{\text {mix }}$ is the vertical entrainment velocity, and $H$ is the thickness of the surface layer. We estimate $v_{\text {mix }}$ through changes in the calculated mixed layer depth (following, for example, Skjelvan et al., 2001), and apply this for the periods with a deepening of the mixed layer, which is the period from September to March seen from the development of the MLD (Fig. 2). During the period from April to August there is a decrease in the MLD, and for this period we apply a background mixing through the base of the mixed layer of $0.1 \mathrm{~m} \mathrm{~d}^{-1}$ (Anderson et al., 2000; Skjelvan et al., 2001), which corresponds to a shallowing of $3.0 \mathrm{~m} \mathrm{month}^{-1}$. The applied entrainment velocities are shown in Table 1. We here define $v_{\text {mix }}$ as negative to get a negative flux when directed into the surface layer.

The flux due to biological activity is given by Eq. (4):

$F_{\text {bio }}^{X}=\Delta \mathrm{DEF}^{X}-F_{\text {vert }}^{X}-F_{\text {atm }}^{X}$.

For the nutrients we assume a negligible atmospheric source, but when calculating the biological production from DIC, $F_{\text {bio }}$ needs to be corrected for the air-sea flux (see below). The resulting fluxes are positive as long as the production is greater than the decay of organic matter, as is the case when there is a net biological uptake, removing DIC and nutrients from the surface layer.

The air-sea flux of carbon can be calculated from the difference in partial pressure of $\mathrm{CO}_{2}$ between seawater and air, the gas transfer velocity $k$, and the solubility of $\mathrm{CO}_{2}$ in seawater, $K_{0}$ :

$F_{\text {atm }}=k K_{0} \Delta p \mathrm{CO}_{2}$,

where

$\Delta p \mathrm{CO}_{2}=p \mathrm{CO}_{2}^{\text {sea }}-p \mathrm{CO}_{2}^{\text {air }}$.

The solubility of $\mathrm{CO}_{2}$ in the Iceland Sea surface water was calculated after Weiss (1974), using long-term monthly mean values of salinity and temperature in the upper $30 \mathrm{~m}$. For the dependence of wind speed on the transfer velocity $k$ we used the parameterisation of Sweeney et al. (2007) after Wanninkhof (1992):

$k=0.27 u^{2} \sqrt{\frac{660}{S c}}$,

where $u$ is the long-term surface wind speed $\left(\mathrm{m} \mathrm{s}^{-1}\right)$, and $S c$ is the Schmidt number. The transfer coefficient was then converted to month $^{-1}$ by multiplying with $(365.25 / 12) \times$ (24/100). 
Table 2. Summary of annual fluxes $\left(\mathrm{mol} \mathrm{m}^{-2} \mathrm{yr}^{-1}\right)$ of carbon, nitrate, phosphate, and silicate to the surface layer (upper $100 \mathrm{~m}$ ) of the Iceland Sea; vertical flux $\left(F_{\text {vert }}\right)$, air-sea flux $\left(F_{\text {atm }}\right)$, and biological production $\left(F_{\text {bio }}\right)$. Negative values indicate a flux into the surface layer. The horizontal fluxes are assumed to balance over the year and were set to zero.

\begin{tabular}{llll}
\hline & $\begin{array}{l}F_{\text {vert }} \\
\left(\mathrm{mol} \mathrm{m}^{-2} \mathrm{yr}^{-1}\right)\end{array}$ & $\begin{array}{l}F_{\text {atm }} \\
\left(\mathrm{mol} \mathrm{m}^{-2} \mathrm{yr}^{-1}\right)\end{array}$ & $\begin{array}{l}F_{\text {bio }} \\
\left(\mathrm{mol} \mathrm{m}^{-2} \mathrm{yr}^{-1}\right)\end{array}$ \\
\hline Carbon & $-2.9 \pm 0.5$ & $-4.4 \pm 1.1$ & $7.3 \pm 1.0^{\mathrm{a}}$ \\
Nitrate & $-0.45 \pm 0.09$ & - & $0.45 \pm 0.14^{\mathrm{b}}$ \\
Phosphate & $-0.026 \pm 0.005$ & - & $0.026 \pm 0.010$ \\
Silicate & $-0.26 \pm 0.06$ & - & $0.26 \pm 0.16$ \\
\hline
\end{tabular}

a corresponds to NCP

$\mathrm{b}$ corresponds to new production

To calculate the partial pressure in the atmosphere from the molar fractions obtained from GLOBALVIEW we used the formulation:

$p \mathrm{CO}_{2, \mathrm{~atm}}=X \mathrm{CO}_{2}\left(P_{\mathrm{b}}-P_{\mathrm{w}}\right)$,

where $P_{\mathrm{b}}$ is the barometric pressure (in atmospheres), and $P_{\mathrm{W}}$ is the saturation water vapour pressure calculated from temperature and salinity in the sea surface layer, according to Cooper et al. (1998). Monthly mean seawater $p \mathrm{CO}_{2}$ values were calculated from observational data over the 13 -year time period in the upper $30 \mathrm{~m}$.

\section{Results}

The deficits of nutrients and DIC in the upper $100 \mathrm{~m}$ decrease from January to March (Fig. 4), as a result of the deepened mixed layer depth (Fig. 2). The increase in the deficits after March, related to biological production, continues until a maximum in September, after which the deficits decrease again. There is a small decrease in deficit in phosphate from May to June, which coincides with an almost unchanged deficit in silicate and a slower rate of change of DIC. At the same time the change in the nitrate deficit continues largely as before (Fig. 4). There is a significant uptake of nutrients from winter to late summer (Fig. 3), but on average the system, never gets fully depleted. The calculated fluxes deduced from a change in the deficits, related to vertical mixing, airsea exchange, and biological production, are presented in the following section and are summarised in Table 2 and Fig. 5.

\subsection{Vertical fluxes}

The calculated vertical fluxes add carbon and nutrients to the mixed layer all year around, even though the fluxes during the period of shallow MLD are small. The annual vertical fluxes of DIC and nutrients to the mixed layer was estimated to be $2.9 \pm 0.5 \mathrm{~mol} \mathrm{C} \mathrm{m}^{-2} \mathrm{yr}^{-1}$, $0.45 \pm 0.09 \mathrm{~mol} \mathrm{~N} \mathrm{~m}^{-2} \mathrm{yr}^{-1}, 0.026 \pm 0.005 \mathrm{~mol} \mathrm{P} \mathrm{m}^{-2} \mathrm{yr}^{-1}$,
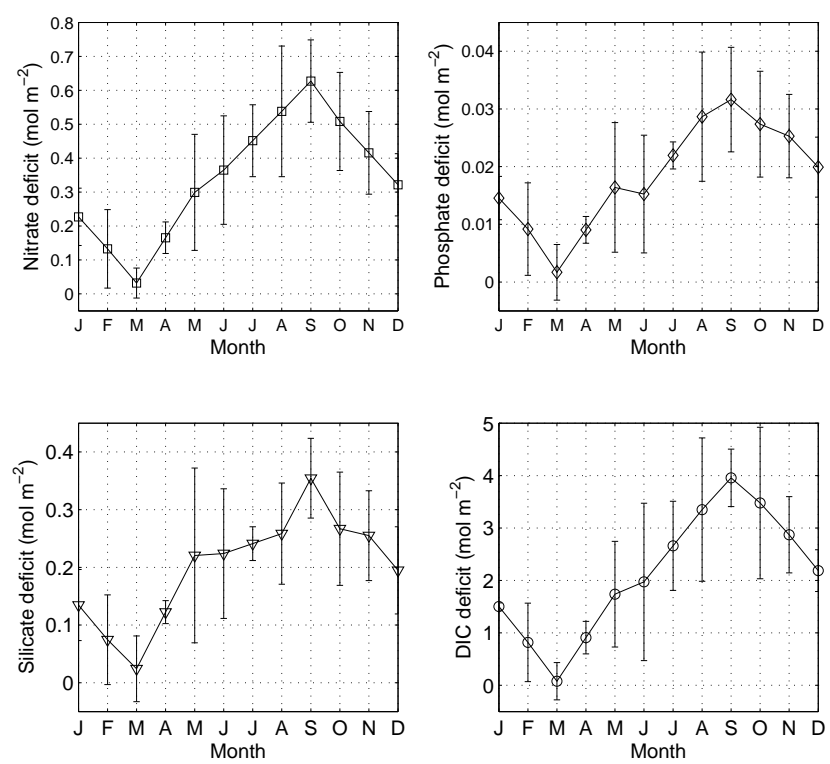

Figure 4. Calculated monthly-mean deficits of nitrate, phosphate, silicate, and carbon, in the upper $100 \mathrm{~m}$ in the Iceland Sea. For the calculations we used mean monthly values for the 100-200 m depth range as reference. The error bars show the propagated error (uncertainty) from the standard deviation of the respective reference concentrations and the average monthly standard deviation in the surface layer. As for the MLD calculations, for the months sampled less than three times in the time series we have used interpolated values. See text for details.

and $0.26 \pm 0.06 \mathrm{~mol} \mathrm{Si} \mathrm{m}^{-2} \mathrm{yr}^{-1}$, for DIC, nitrate, phosphate, and silicate, respectively. The flux of DIC equals $35 \mathrm{~g} \mathrm{C} \mathrm{m}^{-2} \mathrm{yr}^{-1}$. The presented uncertainties are calculated from error propagation of the terms in Eq. (3) (see details in Sect. 6.2).

\subsection{Air-sea flux of $\mathrm{CO}_{2}$}

The air-sea flux is directed into the surface layer all year around, as the region is permanently undersaturated with respect to atmospheric $\mathrm{CO}_{2}$ (Fig. 5). The calculated annual flux was $4.4 \pm 1.1 \mathrm{~mol} \mathrm{C} \mathrm{m}^{-2} \mathrm{yr}^{-1}$, which is consistent with the estimate of Ólafsson et al. (2009) of $4.5 \mathrm{~mol} \mathrm{C} \mathrm{m}^{-2} \mathrm{yr}^{-1}$. When converted, the calculated flux into the Iceland Sea is $53 \mathrm{~g} \mathrm{C} \mathrm{m}^{-2} \mathrm{yr}^{-1}$.

\subsection{Biological production}

The biologically related fluxes of carbon and nutrients all show a two-peak seasonality, with the first maximum in April-May, and a second, larger peak in September. Phosphate shows a slightly different evolution, with no flux in June, and a broader peak in late summer, with a small maximum in August. The nutrients also show a negative flux in October, when there is still a net uptake of carbon. 
Table 3. Stoichiometric (median) ratios of computed monthly vertical fluxes and of biological production during the period of seasonal drawdown (net community uptake).

\begin{tabular}{lll}
\hline & $\begin{array}{l}\text { Vertical flux }^{\mathrm{a}} \\
\text { (annual) }\end{array}$ & $\begin{array}{l}\text { Net uptake }^{\mathrm{a}} \\
\text { (Apr-Sep) }\end{array}$ \\
\hline $\mathrm{N}: \mathrm{P}$ & 18.4 & $18.2^{\mathrm{b}}$ \\
$\mathrm{C}: \mathrm{N}$ & 6.20 & 9.00 \\
$\mathrm{C}: \mathrm{P}$ & 112 & $159^{\mathrm{b}}$ \\
$\mathrm{C}: \mathrm{Si}$ & 11.1 & 25.9 \\
$\mathrm{~N}: \mathrm{Si}$ & 1.67 & 2.72 \\
$\mathrm{Si}: \mathrm{P}$ & 10.5 & $13.3^{\mathrm{b}}$ \\
\hline
\end{tabular}

${ }^{a}$ We use the median of the monthly values since some months show large deviations.

b Since the biologically related flux of phosphate is zero in June these numbers are only based on April-May, and July-September.

The change in the deficit $(\triangle \mathrm{DEF})$ equals zero over the course of the year, and hence there is a balance between the calculated fluxes (Eq. 2). For the nutrients, with the assumption of negligible horizontal and air-sea fluxes, there is a balance between the net vertical fluxes and the net biological fluxes, and the latter amounts to $0.45 \pm 0.14 \mathrm{~mol} \mathrm{~N} \mathrm{~m}^{-2} \mathrm{yr}^{-1}, 0.026 \pm 0.010 \mathrm{~mol} \mathrm{P} \mathrm{m}^{-2} \mathrm{yr}^{-1}$, and $0.26 \pm 0.16 \mathrm{~mol} \mathrm{Si} \mathrm{m}^{-2} \mathrm{yr}^{-1}$, respectively (Table 2). Following the definition of new production (Dugdale and Goering, 1967), and our assumptions of negligible horizontal and air-sea flux of nitrate, the addition of nitrate from vertical mixing must equal new production. In the Iceland Sea this amounts to $0.45 \pm 0.09 \mathrm{~mol} \mathrm{~N} \mathrm{~m}^{-2} \mathrm{yr}^{-1}$.

The biologically driven change in DIC, corrected for vertical flux and air-sea exchange, corresponds to NCP, with positive numbers illustrating net autotrophy, and negative values net heterotrophy. There is a very small or negative NCP in the first part of the year, but from March to October there is a net autotrophic production (Fig. 5). There is also a small positive NCP in December, but this could be due to the fact that the values have been interpolated because there is less data available in December and January. This will not be discussed further.

The net annual NCP corresponds to the export production, when assuming steady state. In the Iceland Sea this sums up to $7.3 \pm 1.0 \mathrm{~mol} \mathrm{C} \mathrm{m}^{-2} \mathrm{yr}^{-1}$, or $88 \pm 12 \mathrm{~g} \mathrm{C} \mathrm{m}^{-2} \mathrm{yr}^{-1}$.

The seasonal drawdown of nitrate, corresponding to the period of net community uptake (i.e. increasing deficit; April to September; see Fig. 4), relates to the total production. This period shows positive biological fluxes, and the sum of these amounts to $0.72 \pm 0.10 \mathrm{~mol} \mathrm{~N} \mathrm{~m}^{-2} \mathrm{yr}^{-1}$. The difference between the new and total production $\left(0.27 \pm 0.15 \mathrm{~mol} \mathrm{~N} \mathrm{~m}^{-2} \mathrm{yr}^{-1}\right)$ gives the regenerated production, which represents $37 \%$ of the total production. Then we get an $f$ ratio (i.e. the ratio between new and total production) of 0.63 in the Arctic domain of the Iceland Sea. Performing the same calculations for phosphate and silicate
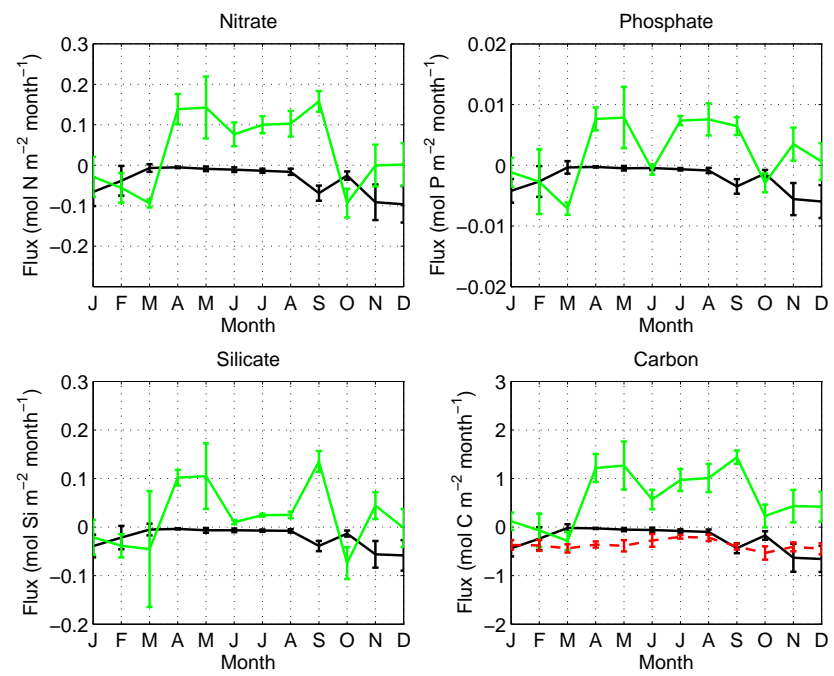

Figure 5. Calculated seasonal fluxes to the upper $100 \mathrm{~m}$ in the Iceland Sea, for nitrate, phosphate, silicate and DIC. All fluxes are in mol m${ }^{-2}$ month $^{-1}$. The figures show the vertical flux $\left(F_{\text {vert }}\right.$; solid black line), the biological production ( $F_{\text {bio }}$; green solid line $)$, and the air-sea flux of $\mathrm{CO}_{2}\left(F_{\mathrm{atm}}\right.$; red dashed line for carbon). The error bars show the propagated errors (see Sect. 6). Note that the scale on the $y$ axis is different for all constituents.

gives a total production of $0.036 \pm 0.006 \mathrm{~mol} \mathrm{P} \mathrm{m}^{-2} \mathrm{yr}^{-1}$ and $0.40 \pm 0.07 \mathrm{~mol} \mathrm{Si} \mathrm{m}^{-2} \mathrm{yr}^{-1}$.

\subsection{Stoichiometry of the calculated fluxes}

An evaluation of the stoichiometric relationships between carbon and nutrients show varying values during the year, as well as for the different fluxes (Table 3).

Evaluating the stoichiometry for the biological production is not straightforward since the flux of carbon and nitrate do not show the same direction for all months. The change in deficits of DIC and nitrate (Fig. 4), however, both show a net uptake from April to September, so we will use this period to evaluate the biologically related stoichiometry. The $\mathrm{C}: \mathrm{N}$ ratios of the monthly biological production (Fig. 7), during the period of seasonal drawdown of DIC and nitrate, differ between the early and the late part of the season, with $\mathrm{C}: \mathrm{N}$ ratios of 8.8-8.9 in April and May, and 9.1-9.8 between July and September, while the value in June is 7.4.

\section{Discussion}

\subsection{Primary production in the central Iceland Sea}

The main aim of this study is to investigate primary production and related stoichiometry in the central Iceland Sea. This domain is dominated by Arctic waters, and is the least productive of the waters around Iceland (e.g. Gudmundsson, 1998; Assthorsson et al., 2007). However, it could be repre- 


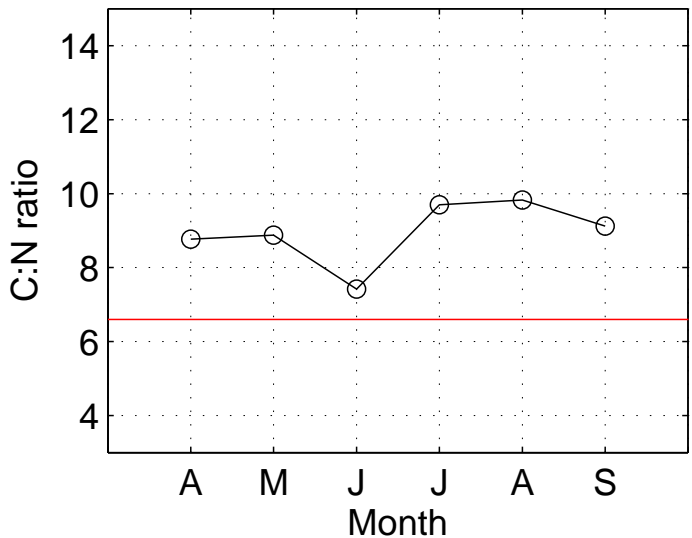

Figure 6. Average monthly $\mathrm{C}: \mathrm{N}$ ratios for biological production (see Fig. 5) during the period of seasonal drawdown (AprilSeptember) of DIC and nitrate in the Iceland Sea. Then red line show the Redfield $\mathrm{C}: \mathrm{N}$ ratio of 6.6.

sentative of the whole Arctic domain in the Nordic Seas, with similar hydro-chemical properties.

How realistic is our estimated annual net production (NCP) of $88 \pm 12 \mathrm{~g} \mathrm{C} \mathrm{m}^{-2} \mathrm{yr}^{-1}$ in the Iceland Sea? Gudfinnsson (2012) found, from his data of daily productivity, an average annual phytoplankton productivity of $65 \mathrm{~g} \mathrm{C} \mathrm{m}^{-2} \mathrm{yr}^{-1}$, and Thordardottir (1984) presented an average annual primary production (1958-1982) in the Arctic domain, in the vicinity of the time series station, of $75 \mathrm{~g} \mathrm{C} \mathrm{m}^{-2} \mathrm{yr}^{-1}$, based on measured ${ }^{14} \mathrm{C}$ uptake at light saturation. A modelling study (Skogen et al., 2007), suggests a mean annual production in the Iceland Sea at $70 \mathrm{~g} \mathrm{C} \mathrm{m}^{-2} \mathrm{yr}^{-1}$, with an $f$ ratio of $\sim 0.7$. These estimates show a large agreement with the estimates in our study, giving more trust in our results, and the approach. The uncertainty in our presented fluxes, and the approach in general, are discussed in Sect. 6.

From remote sensing data, Zhai et al. (2012) gave a production estimate in the Arctic domain of $179 \pm 36 \mathrm{~g} \mathrm{C} \mathrm{m}^{-2} \mathrm{yr}^{-1}$. This is more than twice as high as the estimates based on in situ data. This has also been seen in other comparisons between production estimates based on in situ and remote sensing data (e.g. Richardson et al., 2005; Körtzinger et al., 2008; Frigstad et al., 2015).

The negative nutrient flux in October, when there is still a net uptake of carbon (Fig. 5), is similar to what have been observed in the Norwegian Sea (Falck and Anderson, 2005), which were explained largely by a build-up of dissolved organic matter (DOM), which is relatively low in nutrients. We will discuss this further below, in relation to the stoichiometry of the production.
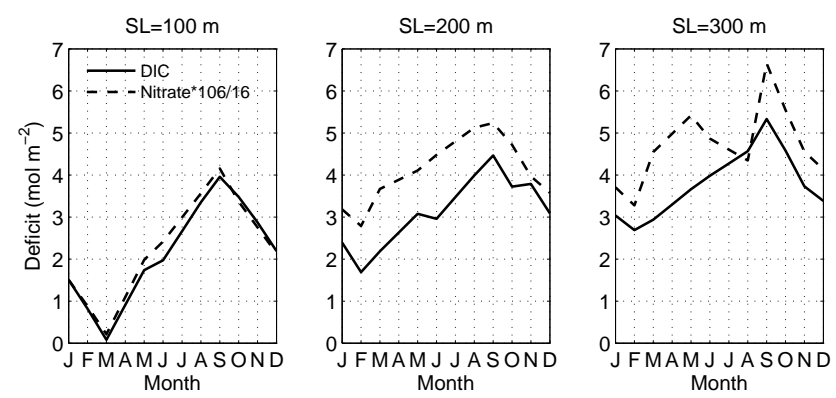

Figure 7. Comparison of calculated monthly-mean deficits of DIC and nitrate in the Iceland Sea, for different thickness of the surface layer (SL). The nitrate deficits are multiplied with the Redfield C : N ratio of 6.6 .

\subsection{Variable stoichiometry}

The evaluation of the $\mathrm{C}: \mathrm{N}$ ratios during seasonal drawdown (April to September) of DIC and nitrate (Fig. 6) showed a clear deviation from the Redfield $\mathrm{C}: \mathrm{N}$ ratio of 6.6 , except in June, when the production was lower. The consumption of carbon relative to nitrate in excess of Redfield, a phenomena termed "carbon overconsumption" (Toggweiler, 1993), was higher during the late summer production $(\mathrm{C}: \mathrm{N}$ ratio $>9)$ compared to the early production peak $(\mathrm{C}: \mathrm{N}$ ratio $<9)$. Similar increases in carbon overconsumption during the later part of the productive season have been described in several studies from different ocean regions, and have been explained by the build up of low-nitrogen DOM (e.g. Toggweiler, 1993; Williams, 1995; Kähler and Koeve, 2001; Körtzinger et al., 2001). Without any data of DOM in the central Iceland Sea we cannot find direct evidence supporting this mechanism in our study, but the similarity to the Atlantic-dominated Norwegian Sea (Falck and Anderson, 2005) suggest that this may be a general feature also in the Nordic Seas. This should be evaluated further in the future. Nonetheless, different mechanisms seem to affect the flux of carbon and nitrogen during the season, as shown for different regions (e.g. Banse, 1994; Kähler and Koeve, 2001; Frigstad et al., 2011).

If we compare the total new production and NCP during the year, from the values in Table 2 , we get a net $\mathrm{C}: \mathrm{N}$ ratio of 16.2. This means that, if we were to convert the computed new production into export production, using the ratios of Redfield et al. (1963) (6.6), or Takahashi et al. (1993) (7.3), we would underestimate the export production by 55-60\%, assuming our estimated export production is reasonable. This confirms the findings of, Sambrotto et al. (1993), who found that the actual carbon production exceeds any estimate based on nitrogen consumption, converted by the Redfield $\mathrm{C}: \mathrm{N}$ ratio, by $36-81 \%$.

This illustrates the problem in converting new production into NCP, or export production, using constant stoichiometric ratios. As discussed by Laws (1991) these terms may not be related, and would assume that nitrate and carbon are assim- 
ilated by autotrophs during new production, in the same ratio as carbon and nitrate are recycled by heterotrophs. Furthermore, $\mathrm{C}: \mathrm{N}$ ratios have been observed to differ both between seasons (e.g. Körtzinger et al., 2001; Frigstad et al., 2011) and between regions (e.g. Koeve, 2006; Tamelander et al., 2013; Frigstad et al., 2014), with values as high as $\sim 15$.

An evaluation of the relationship between DIC and nitrate in the surface water using the time series data (not shown) gives a high agreement with the estimated stoichiometry in the region by Takahashi et al. (1993). However, this value represents the relationship between measured properties in the surface waters over the year, which includes the net effect of air-sea exchange, biological activities, and mixing. Due to this, Banse (1994) cautioned against using observed in situ DIC: nitrate relationships to make statements about elemental ratios during biological production, and respiration, and recommended smaller closed, controllable systems to find mechanistic explanations of uptake ratios in the surface layer.

\subsection{Comparison to production estimates for other parts of the Nordic Seas}

How representative of the Nordic Seas are our estimated production terms in the Iceland Sea? The average NCP in the Nordic Seas, based on an oxygen budget, have been estimated to $\sim 36 \mathrm{~g} \mathrm{C} \mathrm{m}^{-2} \mathrm{yr}^{-1}$ (Falck and Gade, 1999). This is roughly half of the annual NCP we find in the central Iceland Sea. However, to evaluate regional differences we compare with estimates for the different basins in the area.

For the Greenland Sea, Richardson et al. (2005) estimated the annual primary production to $81 \mathrm{~g} \mathrm{C} \mathrm{m}^{-2} \mathrm{yr}^{-1}$, or $70 \mathrm{~g} \mathrm{C} \mathrm{m}^{-2} \mathrm{yr}^{-1}$, if excluding observations within the ice or at the ice edge. Anderson et al. (2000) estimated the annual new production, in the upper $150 \mathrm{~m}$, of $34 \mathrm{~g} \mathrm{C} \mathrm{m}^{-2} \mathrm{yr}^{-1}$, based on a box model similar to ours, and nitrate data (using a C: $\mathrm{N}$ ratio of 7.5). With an $f$ ratio of 0.56 (Smith, 1993) this corresponds to a total production of $61 \mathrm{~g} \mathrm{C} \mathrm{m}^{-2} \mathrm{yr}^{-1}$ (Richardson et al., 2005). The likely range of annual primary production in the Greenland Sea is in the range 60$100 \mathrm{~m}^{-2} \mathrm{yr}^{-1}$ (Richardson et al., 2005), which is in agreement with the range of estimates for the Iceland Sea.

In the Norwegian Sea, the primary production has been estimated to $80 \mathrm{~g} \mathrm{C} \mathrm{m}^{-2} \mathrm{yr}^{-1}$ (Rey, 2004) and that the new production is $60 \%$ of that. It has also been pointed out that where zooplankton grazing is high, as in the Norwegian Sea, new production may be underestimated (Bathmann et al., 1990) and could be as high as $80 \%$. Results from a modelling study (Skogen et al., 2007), suggests a mean annual production in the Norwegian Sea at $65 \mathrm{~g} \mathrm{C} \mathrm{m}^{-2} \mathrm{yr}^{-1}$, with an $f$ ratio of $\sim 0.75$.

Falck and Anderson (2005) used a box model approach similar to the present study, and for the Norwegian Sea, they assumed the export production to correspond to the vertical flux of nutrients to the surface layer (upper $100 \mathrm{~m}$ ), which equalled $0.23 \mathrm{~N} \mathrm{~m}^{-2} \mathrm{yr}^{-1}$, or $18 \mathrm{~g} \mathrm{C} \mathrm{m}^{-2} \mathrm{yr}^{-1}$; when using the traditional Redfield $\mathrm{C}: \mathrm{N}$ ratio (6.6). Their new production estimate amounted to $0.51 \mathrm{~mol} \mathrm{~N} \mathrm{~m}^{-2} \mathrm{yr}^{-1}$, or $41 \mathrm{~g} \mathrm{C} \mathrm{m}^{-2} \mathrm{yr}^{-1}$, using the same ratio. If equating their vertical flux of nitrate with new production, and their total production with the sum of all positive biological fluxes during the year, we get an $f$ ratio of 0.43 . This is clearly lower than the earlier estimates mentioned above (Rey, 2004; Skogen et al., 2007).

Earlier estimates of new production in the Norwegian Sea $\left(70^{\circ} \mathrm{N}, 0^{\circ} \mathrm{E}\right.$ ) are in the range $21-29 \mathrm{~g} \mathrm{C} \mathrm{m}^{-2} \mathrm{yr}^{-1}$ (Bodungen et al., 1995). These values agree with estimates of NCP, based on oxygen fluxes in the Norwegian Sea, of $\sim 24$ $32 \mathrm{~g} \mathrm{C} \mathrm{m}^{-2} \mathrm{yr}^{-1}$ (Skjelvan et al., 2001). The new production estimate is in reasonable agreement with what we estimate for the Iceland Sea, but it is clear that previous NCP estimates based on oxygen budgets are significantly lower than what we get in the Iceland Sea. This could partly be due to the oxygen-to-carbon conversion applied, mostly based on the traditional Redfield ratio, but the only way to unravel real or artificial differences is to analyse the whole region with the same method. This should be pursued in the near future to investigate regional differences, but also to evaluate trends and changes in the system. Nevertheless, the range of methods and approaches, both based on observations and models, and different assumptions, including ours, still seems to reach some consensus of annual primary production in the Nordic Seas of $\sim 60-100 \mathrm{~g} \mathrm{C} \mathrm{m}^{-2} \mathrm{yr}^{-1}$. More work is needed to evaluate regional similarities and differences in stoichiometry and any temporal trends in primary production. This will aid understanding of the variability drivers in biological production, both natural and anthropogenic, and how the increasing levels of atmospheric $\mathrm{CO}_{2}$ will affect the biological carbon pump.

\section{Uncertainties}

One obvious source of error is the fact that our approach only makes long-term averages for all months, so any trends in the observed properties will cause some uncertainty in the resulting values. With this in mind we proceed to evaluate the uncertainty of the approach and the individual fluxes.

\subsection{Deficit calculations}

The uncertainties in the deficit calculations are related to the interannual variability in the observed concentrations in the surface layer and in the sub-surface reference concentrations, and the uncertainties arising from the averaging procedures of the monthly profiles. The uncertainty in the monthly surface layer concentrations (seen from the average monthly standard deviation) is largest for silicate (values up to 40$50 \%$ ), but for nitrate and phosphate there is a maximum in late summer/early autumn, when the concentrations are lowest by $20-30 \%$. Due to the high concentrations of DIC the 
uncertainty in these numbers is insignificant. If we propagate the uncertainties in the surface concentrations and the reference concentrations and use this as the overall uncertainty in the monthly deficits we get the values depicted in Fig. 4, which are quite substantial for some of the months, with a relative error of up to $60-75 \%$ at or just after the early peak in production, but lower (10-40\%) during the later part of the year. The uncertainty in the values from the first part of the year, during the period of deepened mixed layer, is rather low in an absolute sense, compared to later in the year, but due to the low deficits in this period the relative errors get very large (see Fig. 4).

There is a potential error in assessing the production, and related terms, in the upper $100 \mathrm{~m}$, when the MLD apparently reaches deeper in winter. However, the vertical distribution of nutrients and DIC do show a homogeneous upper $100 \mathrm{~m}$ in winter, followed by a gradient down to stable concentration at depths below $\sim 300 \mathrm{~m}$. Profiles of salinity show the same feature (Fig. 3). Deficits were also calculated for the upper $200 \mathrm{~m}$ (referenced to the monthly means between 100 and $200 \mathrm{~m}$ ), and the upper $300 \mathrm{~m}$ (referenced to the monthly means between 300 and $400 \mathrm{~m}$ ). The resulting deficits of carbon and nutrients showed an increasing degree of decoupling with increasing depth of the surface layer, as shown in Fig. 7. The $\mathrm{C}: \mathrm{N}$ ratio during the period of net biological uptake also varies considerably more with thicker surface layer (not shown) compared to the upper $100 \mathrm{~m}$. With a surface layer down to $200 \mathrm{~m}$ the $\mathrm{C}: \mathrm{N}$ uptake ratio is 20 during the spring peak, below 4 in June, and shows values between 13 and 19 from July to September. A surface layer of $300 \mathrm{~m}$ gives C : N uptake ratios of 10 during the spring peak, followed by negative values during summer, and a value of 4 in September. This suggests that processes other than biological assimilation contributed much more to the distribution of nutrients and carbon at these depths Since we mainly want to evaluate the fluxes of importance for the production, and these seem to be confined to the upper $100 \mathrm{~m}$, we argue that the applied method best captures the biological production with the relatively shallow surface layer we use. This may also be connected to the different water masses present in the Iceland Sea, so it is important to evaluate different surface layer thickness in different regions.

\subsection{Vertical flux}

The uncertainty in the vertical fluxes could be significant. With the assumption that the air-sea fluxes, as well as the horizontal fluxes of nutrients could be neglected, the increase in nutrient concentration during periods of deepened mixed layer depths should equal the vertical fluxes. Since we estimate the vertical entrainment velocity from the observed changes in MLD, there is both an uncertainty related to the chosen method to calculate MLD, and the variability in the monthly MLD during the time series. The variabilitydriven uncertainty in the mean monthly MLD is on average $\sim 30 \%$ (Fig. 2). The calculated uncertainty in the vertical fluxes of DIC, and nutrients are all in the range 17-22\% (see Table 2).

\subsection{Air-sea exchange}

From the propagation of the errors due to spread in mean $p \mathrm{CO}_{2}$ values for atmosphere and sea surface, and putting this error estimate in the flux calculation for each month, we get an annual uncertainty of $1.1 \mathrm{~mol} \mathrm{C} \mathrm{m}^{-2}$, which is $25 \%$ of the estimated annual flux. This agrees with previous findings from the North Atlantic and the Nordic Seas (Körtzinger et al., 2001; Olsen et al., 2003). Körtzinger et al. (2008) have estimated a maximum error in calculated $\mathrm{CO}_{2}$ fluxes of $40 \%$.

\subsection{Biological production}

Since the biological production is calculated as the residual of all other terms (Eq. 4) it also carries the uncertainty of each of these terms. Some of the uncertainty could be connected to interannual variability in the timing of the peak in the productive events, something that should be evaluated further in later studies. To estimate the uncertainty in the $\triangle \mathrm{DEF}$ term we use the relative error in the calculated deficits, and multiply these with the $\triangle \mathrm{DEF}$ values for each month, for each constituent. The relative error in the deficit for the months with very low values (February-March) is unrealistically large. For these months we instead use the uncertainty in MLD as the minimum error. For February this is $\sim 50 \%$, and for March $\sim 30 \%$. The total estimated errors in the biologically related fluxes are in the range $31-61 \%$ for the nutrients (highest for silicate), but only $14 \%$ for carbon (Table 2).

\section{Conclusions}

The computed monthly fluxes of dissolved inorganic carbon, nitrate, phosphate and silicate in the Iceland Sea show similarities in the seasonality, but also a decoupling during the year, illustrating different mechanisms effecting the uptake and remineralisation of the different constituents. We estimate an Iceland Sea new production of $0.45 \pm 0.09 \mathrm{~mol} \mathrm{~N} \mathrm{~m}^{-2} \mathrm{yr}^{-1}$, based on nitrate added to the surface layer via vertical mixing, and an annual net community production (NCP) of $7.3 \pm 1.0 \mathrm{~mol} \mathrm{C} \mathrm{m}^{-2} \mathrm{yr}^{-1}$ (or $\left.88 \pm 12 \mathrm{~g} \mathrm{C} \mathrm{m}^{-2} \mathrm{yr}^{-1}\right)$. The presented NCP shows a high agreement with earlier estimates of primary production in the Iceland Sea, and to other parts of the Nordic Seas. The estimated $\mathrm{C}: \mathrm{N}$ ratios during net biological uptake are in the range 7.4-9.8, and thus indicate that a conversion of the nitrate-based new production to carbon using traditional Redfield $\mathrm{C}: \mathrm{N}$ would markedly underestimate the primary production in the Iceland Sea. 
Acknowledgements. We thank the two anonymous reviewers for helpful comments. This research was supported from the European Union FP7 projects GreenSeas (265294), EURO-BASIN (264933), and, CarboChange (264879). Siv Lauvset is acknowledged for valuable help with netctd files.

Edited by: E. Marañón

\section{References}

Anderson, L. A. and Sarmiento, J. L.: Redfield ratios of remineralization determined by nutrient data analysis, Global Biogeochem. Cy., 8, 65-80, 1994.

Anderson, L. G., Drange, H., Chierici, M., Fransson, A., Johannessen, T., Skjelvan, I., and Rey, F.: Annual carbon fluxes in the upper Greenland Sea based on measurements and a box-model approach, Tellus B, 52, 1013-1024, 2000.

Astthorsson, O. S., Gislason, A., and Jonsson, S.: Climate variability and the Icelandic marine ecosystem, Deep-Sea Res. PT II, 54, 2456-2477, 2007.

Banse, K.: Uptake of inorganic carbon and nitrate by marine plankton and the Redfield Ratio, Global Biogeochem. Cy., 8, 81-84, 1994.

Bathmann, U. V., Peinert, R., Noji, T. T., and Bodungen, B. V.: Pelagic origin and fate of sedimenting particles in the Norwegian Sea, Prog. Oceanogr., 24, 117-125, 1990.

Bodungen, B. V., Anita, A., Bauerfeind, E., Haupt, O., Koeve, W., Machado, E., Peeken, I., Peinert, R., Reitmeier, S., Thomsen, C., Voss, M., Wunsch, M., Zeller, U., and Zeitzschel, B.: Pelagic processes and vertical flux of particles: an overview of a longterm comparative study in the Norwegian Sea and Greenland Sea, Geol. Rundsch., 84, 11-27, 1995.

Church, M. J., Lomas, M. W., and Muller-Karger, F.: Sea change: Charting the course for biogeochemical ocean time-series research in a new millennium, Deep-Sea Res. PT II, 93, 2-15, 2013.

Cooper, D. J., Watson, A. J., and Ling, R. D.: Variations of $P_{\mathrm{CO}_{2}}$ along a North Atlantic shipping route (UK to the Caribbean): A year of automated observations, Mar. Chem., 60, 147-164, 1998.

Daly, K. L., Wallace, D. W. R., Smith, W. O., Jr., Skoog, A., Lara, R., Gosselin, M., Falck, E., and Yager, P. L.: Non-Redfield carbon and nitrogen cycling in the Arctic: Effects of ecosystem structure and dynamics, J. Geophys. Res., 104, 3185-3199, 1999.

de Boyer Montégut, C., Madec, G., Fischer, A. S., Lazar, A., and Iudicone, D.: Mixed layer depth over the global ocean: An examination of profile data and a profile-based climatology, J. Geophys. Res., 109, C12003, doi:10.1029/2004JC002378, 2004.

Dugdale, R. C. and Goering, J. J.: Uptake of new and regenerated forms of nitrogen in primary productivity, Limnol. Oceanogr., 23, 196-206, 1967.

Eppley, R. W. and Peterson, B. J.: Particulate organic matter flux and planktonic new production in the deep ocean, Nature, 282, 677-680, 1979.

Evans, G. T. and Parslow, J. S.: A model of annual plankton cycles, Biol. Oceanogr., 3, 327-347, 1985.

Falck, E. and Anderson, L. G.: The dynamics of the carbon cycle in the surface water of the Norwegian Sea, Mar. Chem., 94, 43-53, 2005.
Falck, E. and Gade, H. G.: Net community production and oxygen fluxes in the Nordic Seas based on $\mathrm{O}_{2}$ budget calculations, Global Biogeochem. Cy., 13, 1117-1126, 1999.

Falkowski, P. G., Barber, R. T., and Smetacek, V.: Biogeochemical Controls and Feedbacks on Ocean Primary Production, Science, 281, 200-206, 1998.

Frigstad, H., Andersen, T., Hessen, D. O., Naustvoll, L.-J., Johnsen, T. M., and Bellerby, R. G. J.: Seasonal variation in marine $\mathrm{C}: \mathrm{N}: \mathrm{P}$ stoichiometry: can the composition of seston explain stable Redfield ratios?, Biogeosciences, 8, 2917-2933, doi:10.5194/bg-8-2917-2011, 2011.

Frigstad, H., Andersen, T., Bellerby, R. G. J., Silyakova, A., and Hessen, D. O.: Variation in the seston $\mathrm{C}: \mathrm{N}$ ratio of the Arctic Ocean and pan-Arctic shelves, J. Marine Syst., 129, 214-223, 2014.

Frigstad, H., Henson, S. A., Hartman, S. E., Cole, H., Omar, A. M., Jeansson, E., Pebody, C., and Lampitt, R. S.: Links between surface productivity and deep ocean particle flux at the Porcupine Abyssal Plain (PAP) sustained observatory, in preparation, 2015.

Fritsch, F. N. and Carlson, R. E.: Monotone Piecewise Cubic Interpolation, SIAM J. Numer. Anal., 17, 238-246, 1980.

Gaarder, T. and Gran, H. H.: Investigation of the production of phytoplankton in the Oslo Fjord, Rapp. P.V. Cons. Int. Explor. Mer, 42, 1-48, 1927.

GLOBALVIEW-CO2: Cooperative Atmospheric Data Integration Project - Carbon Dioxide, NOAA, GMD, Boulder, Colorado, available via anonymous FTP to ftp://ftp.cmdl.noaa.gov, Path: ccg/co2/GLOBALVIEW, 2012.

Guðfinnsson, H. G.: Breytingar á blaðgrænumagni, frumframleiðni og tegundasamsetningu svifpörunga í Íslandhafi/Changes in chlorophyll a, primary production and species composition in the Iceland Sea. Technical Report Hafrannsóknastofnunin (Marine Research Institute), Reykjavík, 164, 45-67, 2012 (in Icelandic).

Gudmundsson, K.: Long-term variation in phytoplankton productivity during spring in Icelandic waters, ICES J. Mar. Sci., 55, 635-643, 1998.

Kähler, P. and Koeve, W.: Marine dissolved organic matter: can its $\mathrm{C}: \mathrm{N}$ ratio explain carbon overconsumption?, Deep-Sea Res. PT I, 4, 49-62, 2001.

Kalnay, E., Kanamitsu, M., Kistler, R., Collins, W., Deaven, D., Gandin, L., Iredell, M., Saha, S., White, G., Woollen, J., Zhu, Y., Leetmaa, A., Reynolds, R., Chelliah, M., Ebisuzaki, W., Higgins, W., Janowiak, J., Mo, K. C., Ropelewski, C., Wang, J., Jenne, R., and Joseph, D.: The NCEP/NCAR 40-Year Reanalysis Project, B. Am. Meteorol. Soc., 77, 437-471, 1996.

Koeve, W.: C:N stoichiometry of the biological pump in the North Atlantic: Constraints from climatological data, Global Biogeochem. Cy., 20, GB3018, doi:10.1029/2004GB002407, 2006.

Körtzinger, A., Koeve, W., Kähler, P., and Mintrop, L.: C : N ratios in the mixed layer during the productive season in the northeast Atlantic Ocean, Deep-Sea Res. PT I, 48, 661-688, 2001.

Körtzinger, A., Send, U., Lampitt, R. S., Hartman, S., Wallace, D. W. R., Karstensen, J., Villagarcia, M. G., Llinás, O., and DeGrandpre, M. D.: The seasonal $p \mathrm{CO}_{2}$ cycle at $49^{\circ} \mathrm{N} / 16.5^{\circ} \mathrm{W}$ in the northeastern Atlantic Ocean and what it tells us about biological productivity, J. Geophys. Res., 113, C04020, doi:10.1029/2007JC004347, 2008. 
Laws, E. A.: Photosynthetic quotient, new production and net community production in the open ocean, Deep-Sea Res., 38, 143$167,1991$.

Ólafsson, J.: Winter mixed layer nutrients in the Irminger and Iceland Seas, 1990-2000, ICES Mar. Sc., 219, 329-332, 2003.

Ólafsson, J. and Olsen, A.: Nordic Seas nutrients data in CARINA, Earth Syst. Sci. Data, 2, 205-213, doi:10.5194/essd-2-205-2010, 2010.

Ólafsson, J., Ólafsdottir, S. R., Benoit-Cattin, A., Danielsen, M., Arnarson, T. S., and Takahashi, T.: Rate of Iceland Sea acidification from time series measurements, Biogeosciences, 6, 26612668, doi:10.5194/bg-6-2661-2009, 2009.

Ólafsson, J., Ólafsdottir, S. R., Benoit-Cattin, A., and Takahashi, T.: The Irminger Sea and the Iceland Sea time series measurements of sea water carbon and nutrient chemistry 1983-2008, Earth Syst. Sci. Data, 2, 99-104, doi:10.5194/essd-2-99-2010, 2010.

Olsen, A., Bellerby, R. G. J., Johannessen, T., Omar, A. M., and Skjelvan, I.: Interannual variability in the wintertime air-sea flux of carbon dioxide in the northern North Atlantic, 1981-2001, Deep-Sea Res. PT I, 50, 1323-1338, 2003.

Olsen, A.: Nordic Seas total dissolved inorganic carbon data in CARINA, Earth Syst. Sci. Data, 1, 35-43, doi:10.5194/essd-1-352009, 2009.

Pálsson, Ó. K., Gislason, A., Gudfinnsson, H. G., Gunnarsson, B., Ólafsdóttir, S. R., Petursdottir, H., Sveinbjörnsson, S., Thorisson, K., and Valdimarsson, H.: Ecosystem structure in the Iceland Sea and recent changes to the capelin (Mallotus villosus) population, ICES J. Mar. Sci., 69, 1242-1252, 2012.

Passow, U. and Carlson, C.A.: The biological pump in a high $\mathrm{CO}_{2}$ world, Mar. Ecol.-Prog. Ser., 470, 249-271, 2012.

Platt, T., Harrison, W. G., Lewis, M. R., Li, W. K. W., Sathyendranath, S., Smith, R. E., and Vezina, A. F.: Biological production of the oceans: the case for a consensus, Mar. Ecol.-Prog. Ser., 52, 77-88, 1989.

Quay, P., Stutsman, J., and Steinhoff, T.: Primary production and carbon export rates across the subpolar N. Atlantic Ocean basin based on triple oxygen isotope and dissolved $\mathrm{O}_{2}$ and Ar gas measurements, Global Biogeochem. Cy., 26, GB2003, doi:10.1029/2010GB004003, 2012.

Redfield, A. C., Ketchum, B. H., and Richards, F.A.: The influence of organisms on the composition of seawater, in: The Sea, edited by: Hill, M. N., John Wiley, New York, 26-77, 1963.

Reuer, M. K., Barnett, B. A., Bender, M. L., Falkowski, P. G., and Hendricks, M. B.: New estimates of southern ocean biological production rates from $\mathrm{O}_{2} \mathrm{Ar}^{-1}$ ratios and the triple isotope composition of $\mathrm{O}_{2}$, Deep-Sea Res. PT I, 54, 951-974, 2007.

Rey, F.: Phytoplankton: the grass of the sea, in: The Norwegian Sea Ecosystem, edited by: Skjoldal, H. R., Tapir Academic Press, Trondheim, Norway, 97-136, 2004.

Richardson, K., Markager, S., Buch, E., Lassen, M. F., and Kristensen, A. S.: Seasonal distribution of primary production, phytoplankton biomass and size distribution in the Greenland Sea, Deep-Sea Res. PT I, 52, 979-999, 2005.
Sabine, C. L., Feely, R. A., Gruber, N., Key, R. M., Lee, K., Bullister, J. L., Wanninkhof, R., Wong, C. S., Wallace, D. W. R., Tilbrook, B., Millero, F. J., Peng, T.-H., Kozyr, A., Ono, T., and Rios, A. F.: The oceanic sink for anthropogenic $\mathrm{CO}_{2}$, Science, 305, 367-371, 2004.

Sambrotto, R. N., Savidge, G., Robinson, C., Boyd, P., Takahashi, T., Karl, D. M., Langdon, C., Chipman, D., Marra, J., and Codispoti, L.: Elevated consumption of carbon relative to nitrogen in the surface ocean, Nature, 363, 248-250, 1993.

Skjelvan, I., Falck, E., Anderson, L. G., and Rey, F.: Oxygen fluxes in the Norwegian Atlantic Current, Mar. Chem., 73, 291-303, 2001.

Skjelvan, I., Falck, E., Rey, F., and Kringstad, S. B.: Inorganic carbon time series at Ocean Weather Station $M$ in the Norwegian Sea, Biogeosciences, 5, 549-560, doi:10.5194/bg-5-549-2008, 2008.

Skogen, M. Budgell, W. P., and Rey, F.: Interannual variability in Nordic Seas primary production, ICES J. Mar. Sci., 64, 889-898, 2007.

Smith, W. O.: Nitrogen uptake and new production in the Greenland Sea: The spring Phaeocystis bloom, J. Geophys. Res., 98, 46814688, 1993.

Sweeney, C., Gloor, E., Jacobson, A. R., Key, R. M., McKinley, G., Sarmiento, J. L., and Wanninkhof, R.: Constraining global air-sea gas exchange for $\mathrm{CO}_{2}$ with recent bomb ${ }^{14} \mathrm{C}$ measurements, Global Biogeochem. Cy., 21, GB2015, doi:10.1029/2006GB002784, 2007.

Swift, J. H. and Aagaard, K.: Seasonal transitions and water mass formation in the Iceland and Greenland seas, Deep-Sea Res., 28, 1107-1129, 1981.

Tamelander, T., Reigstad, M., Olli, K., Slagstad, D., and Wassmann, P.: New production regulates export stoichiometry in the ocean, PLoS ONE, 8, e54027, doi:54010.51371/journal.pone.0054027, 2013.

Takahashi, T., Ólafsson, J., Goddard, J. G., Chipman, D. W., and Sutherland, S. C.: Seasonal variations of $\mathrm{CO}_{2}$ and nutrients in the high-latitude surface oceans: A comparative study, Global Biogeochem. Cy., 7, 843-878, 1993.

Thordardottir, T.: Primary production north of Iceland in relation to water masses in May-June 1970-1989, International Council for the Exploration of the Sea, CM 1984/L:20, 17 pp., 1984.

Toggweiler, J. R.: Carbon overconsumption, Nature, 363, 210-211, 1993.

Wanninkhof, R.: Relationship Between Wind Speed and Gas Exchange Over the Ocean, J. Geophys. Res., 97, 7373-7382, 1992.

Weiss, R. F.: Carbon dioxide in water and seawater: The solubility of a non-ideal gas, Mar. Chem., 2, 203-215, 1974.

Williams, P. J. I.: Evidence for the seasonal accumulation of carbonrich dissolved organic material, its scale in comparison with changes in particulate material and the consequential effect on net $\mathrm{C} / \mathrm{N}$ assimilation ratios, Mar. Chem., 51, 17-29, 1995.

Zhai, L., Gudmundsson, K., Miller, P., Peng, W., Guðfinnsson, H., Debes, H., Hátún, H., White Iii, G. N., Hernández Walls, R., Sathyendranath, S., and Platt, T.: Phytoplankton phenology and production around Iceland and Faroes, Cont. Shelf Res., 37, 1525, doi:10.1016/j.csr.2012.01.013, 2012. 